\title{
DESORDEM À VISTA: A MÚSICA NAS MEMÓRIAS DE UM SARGENTO DE MILÍCIAS, DE MANUEL ANTÔNIO DE ALMEIDA
}

\author{
Luiz Filipe Correia ${ }^{22}$ \\ Said Tuma ${ }^{23}$
}

\begin{abstract}
RESUMO
O artigo explora relações entre música e literatura. Apoia-se em pesquisa histórica de natureza interdisciplinar e utiliza, de forma privilegiada, fontes como obras literárias e musicais. Partindo da dialética da malandragem, definida por Antonio Candido (1970), o artigo investiga como a arte dos sons dialoga com essa reflexão. Além da ubiquidade da música nas Memórias de um Sargento de Milícias (1854-55), de Manuel Antônio de Almeida (1831-1861), a reflexão constata que ela age como um vetor que favorece a passagem da ordem para a desordem. Além da retomada do texto de Antonio Candido, o artigo se justifica pela oportunidade de investigação de práticas musicais brasileiras.

Palavras-chave: Música e literatura; Dialética da malandragem; Manuel Antônio de Almeida; Memórias de um Sargento de Milícias
\end{abstract}

\begin{abstract}
The article explores relations between music and literature. It is grounded on interdisciplinary historical research and makes use, in a privileged manner, of sources such as literary and musical works. Departing from the trickster dialectics (dialética da malandragem), defined by Antonio Candido (1970), the article investigates how the art of sounds dialogues with such thinking. Besides the ubiquity of music in Memoirs of a Militia Sergeant (1854-55), of Manuel Antônio de Almeida (1831-1861), the reflection notes that music acts as a vector favoring the passage from order to disorder. Besides the approach of the text of Antonio Candido, the article is justified by the opportunity of investigation in Brazilian musical practices.

Key-words: Music and literature; Dialética da malandragem; Manuel Antônio de Almeida; Memoirs of a Militia Sergeant

\section{INTRODUÇÃO}

\footnotetext{
${ }^{22}$ Luiz Filipe Correia é historiador. Fez seu mestrado e doutorado em história social pela FFLCH-USP. Realiza pesquisas sobre os intercâmbios entre cultura e tecnologia, com enfoque em literatura, cinema, música, arte e cultura material. No mestrado, estudou as relações entre história, música, cultura e tecnologia. Atualmente, faz bacharelado em Letras Português/Inglês na Universidade de São Paulo.

${ }^{23}$ Said Tuma é pianista e pesquisador em musicologia histórica. Fez mestrado e doutorado em musicologia histórica na Escola de Comunicações e Artes da Universidade de São Paulo. Pesquisa os usos da história da música como instrumento de educação e divulgação musicais e as relações entre música e patrimônio musical. Leciona a disciplina Música e Patrimônio Cultural no curso de especialização lato sensu História: Arte, Patrimônio e Cultura do Centro Universitário Assunção, Unifai. Apresentase também em recitais nas mais variadas formações musicais.
}

Revista Lumen, v. 4, $\mathrm{n}^{\circ}$ 7, Jan./Jun. - 2019 - ISSN: 2447-8717 
Este ensaio é o resultado de um trabalho de aproximadamente um ano e meio de pesquisas que realizamos em conjunto e que tinha como preocupação inicial as conexões entre as chamadas música erudita e música popular ${ }^{24}$. Posteriormente, nossa atenção se voltou para as relações entre literatura e música - o que culminou no curso Diálogos entre Música e Literatura, ministrado no Sesc Belenzinho entre os meses de maio e junho de 2019. No decorrer da preparação das aulas do curso, nos debruçamos sobre a obra de Manuel Antônio de Almeida num esforço de mapear o lugar da música na literatura. Logo percebemos que a música tinha uma posição de destaque no universo narrado pelo autor, fosse na descrição de costumes, ritos, práticas seculares e profanas ou mesmo na variedade de termos relacionados ao universo musical. Outro fato relevante nos chamou a atenção, Manuel Antônio de Almeida foi diretor da Imperial Academia de Música e Ópera Nacional, cargo que ocupou até a extinção da entidade em 1860 e teve a sua biografia fortemente marcada pela presença da música (ANDRADE, 1941). Quando estávamos preparando a última aula do curso, tivemos a ideia de pensar na música como uma chave de leitura para as Memórias e este ensaio é o resultado de algumas considerações iniciais sobre o tema.

Embora não tenha alcançado sucesso de público à época de sua publicação (ANDRADE, 1941, p. 184), Memórias de um Sargento de Milícias tem despertado a atenção e sido objeto da análise de diversos intelectuais. Esses trabalhos, cada um ao seu modo, procuram interpretar o livro de Manuel Antônio de Almeida a partir de diversas perspectivas, seja inserindo o livro em uma tradição literária (romance picaresco), seja classificando as Memórias como um pioneiro dos romances de costumes e do realismo brasileiro, ou mesmo identificando nele elementos que expliquem aspectos da nacionalidade e da cultura do país ${ }^{25}$.

Um dos motivos para o interesse da crítica talvez esteja relacionado à difícil classificação do livro, ou mesmo ao fato dele conter poucos elementos da tradição do Romantismo brasileiro na qual a obra está cronologicamente inserida. Memórias foi publicado na Pacotilha do Correio Mercantil, em formato de folhetim entre 1852 e 1853; nesse período, o Romantismo, a partir da tradição europeia, estava em plena difusão no Brasil ${ }^{26}$. De maneira geral, o livro de Manuel Antônio de Almeida é considerado "lateral na história do nosso romantismo" (BOSI, 1982, p.148). No entanto, quando analisado fora da superfície classificatória do movimento, é possível encontrar nele pontos de contato com a produção romântica do período no Brasil ${ }^{27}$. Mesmo quando comparado com um dos principais representantes do Romantismo

\footnotetext{
${ }^{24} \mathrm{O}$ crítico Alex Ross explica que essas definições podem ser arbitrárias e acabam por impor juízos de valores a determinados estilos musicais. E ele complementa: "Há pelo menos um século, a música tem sido escrava de um culto elitista medíocre que tenta fabricar autoestima agarrando-se a fórmulas vazias de superioridade intelectual. [...] A música é um meio pessoal demais para sustentar uma hierarquia absoluta de valores. A melhor música é a que nos persuade de que não existe outra música no mundo". (ROSS, 2010, p. 19-20)

${ }^{25}$ Cf. os trabalhos de José Veríssimo (1894), Mário de Andrade (1941), Darcy Damasceno (1956), Antonio Candido (1970) e Roberto Schwarz (1987).

${ }^{26}$ Segundo Alfredo Bosi, a cronologia da ficção romântica começa com Joaquim Manuel de Macedo na década de 1840 , embora, segundo o estudioso, o representante central do movimento seja José de Alencar que começou a publicar sua obra a partir de 1856 (BOSI, 1982. p.143).

${ }^{27}$ Para Schwarz (1987) o que caracteriza o aspecto romântico das Memórias de um Sargento de Milícias é a sua abundante cor local resultante de um esforço patriótico de consolidar uma identidade e uma literatura nacional, que é uma característica típica do romantismo (p.136).
} 
brasileiro, O Guarani de José de Alencar, é possível encontrar pontos em comum com as Memórias. O primeiro é que ambas as obras foram publicadas em jornais periódicos, no formato de folhetim, que foi um dos gêneros literários mais populares no século XIX. Uma das razões para o sucesso do folhetim estava relacionada ao apelo popular das publicações (seja em termos de custo ${ }^{28}$ ou de temas) e às estratégias usadas pelos autores para manter a atenção dos leitores ${ }^{29}$. Tanto as Memórias de um Sargento de Milicias quanto $O$ Guarani utilizam algumas estratégias típicas do romance de folhetim, dentre as quais: a presença de "ganchos" entre os capítulos, usados para provocar suspense e desejo de continuar a leitura; a adoção de recordatórios temporais e explicações do narrador aos leitores quanto às suas escolhas narrativas ${ }^{30}$.

Para além da publicação em folhetim, a presença da música também pode ser considerada como um ponto em comum entre os dois romances - uma vez que as duas obras contam com episódios diretamente relacionados à arte dos sons. É bem verdade que durante o período romântico a música se tornou a expressão artística que servia de inspiração para as outras artes, daí não seja coincidência o fato de José de Alencar ter dado o nome de Xácara ${ }^{31}$ para um capítulo de O Guarani e tenha falado da guitarra espanhola em três momentos de sua narrativa. As referências musicais ajudaram na ambientação de $O$ Guarani no início do século XVII, quando as coroas da Espanha e de Portugal se encontravam unidas. Estudos musicológicos mostram que a música desse período soava espanhola, tempo de gêneros musicais como os villancicos ${ }^{32}$ e os tonos $^{33}$ e período em que obras literárias e peças de teatro eram escritas em castelhano (BUDASZ, 2004, p. 11). Já em Memórias de um Sargento de Milícias, como dito anteriormente, a música é um elemento que atravessa toda a obra. Ela não desempenha papel apenas de ambientação mas, como se verá, tem função estruturante. A descrição pormenorizada das procissões, do fado e das modinhas tocadas por Vidinha, são, possivelmente, um dos fatores que chamaram a atenção dos autores que classificaram o livro de Manuel Antônio de Almeida como pioneiro do romance de costumes ${ }^{34}$.

\footnotetext{
${ }^{28} \mathrm{Em}$ que se pese que os preços ainda fossem proibitivos para as classes mais pobres e a taxa de analfabetismo no país atingisse mais de $70 \%$ da população.

${ }^{29}$ Sobre o folhetim ver (MEYER, 1996). Entre as estratégias citadas pela autora estão: a estrutura iterativa que "não é só chamariz para segurar o público mas a cadeia de coincidências que também tem significado"; criação de tramas paralelas; redundância narrativa; "suspense, reviravoltas, linguagem retórica e chapada, personagens e situações estereotipadas"; estrutura de ardis, entre outras. Curiosamente o livro de Manuel Antônio de Almeida não é citado em nenhum momento do livro, enquanto $O$ Guarani recebe ao menos cinco menções.

${ }^{30}$ Ainda quanto aos aspectos narrativos entre os dois textos, é possível notar uma diferença: enquanto em $O$ Guarani o narrador não se remete em nenhum momento ao leitor, o narrador de Manuel Antônio de Almeida fala diretamente ao leitor mais de 70 vezes no decorrer de toda a história.

${ }^{31}$ No Dicionário Musical Brasileiro aparece uma definição dada por Marisa Lira, segundo a qual Xácara é "uma canção espanhola do séc. XVI, que se canta como as seguidilhas, ao som alegre das violas [...]” (apud ANDRADE, 1989, p. 571).

${ }^{32} \mathrm{O}$ villancico é um tipo de canção a várias vozes espanhola, com muitas estrofes e um refrão. Teve origem secular, mas a partir do século XVII essa forma passou a ser usada em obras sacras associadas ao Cristo ou a outros dias sagrados (BURKHOLDER, 2010, p. A20).

33 Os tonos eram formas de canções eruditas bastante difundidas na Península Ibérica e na América Latina. Texto em espanhol, temática árcade, forma estrófica com refrão (BUDASZ, 2004, p. 11).

${ }^{34}$ Para além desse prestígio da música em relação às outras artes, e talvez por conta dele, é preciso destacar que fosse popular ou erudita, a música era um elemento presente na sociedade brasileira em fins do século XIX, sendo um tema amplamente abordado na literatura nacional.
} 
Entre os diversos textos que analisaram Memórias de um Sargento de Milícias os que serviram de base para este ensaio são o prefácio escrito por Mário de Andrade para a edição da obra de 1941; a revisão crítica e análise propostas na Dialética da Malandragem publicada por Antonio Candido em 1970 e, por fim, Os pressupostos, salvo engano, da Dialética da Malandragem, texto de Roberto Schwarz publicado em 1987. Embora esses três trabalhos tenham se tornado basilares da crítica relativa ao livro e serem influência e fonte de leituras e análises críticas posteriores, com exceção do texto de Mário de Andrade, há um certo silêncio em relação à presença da música nas Memórias nas obras citadas. Em Antonio Candido (1970) esse "silêncio" é quebrado por duas únicas referências musicais externas ao livro: a aproximação que ele faz de Vidinha à 'moreninha 'amigada' com o tropeiro, que amenizou a estadia do mercenário alemão Schlichthorst no Rio de Janeiro daquele tempo, cantando modinhas sentada na esteira, junto com a mãe complacente" (CANDIDO, 1970, p. 79); e a menção à ópera de Verdi para comparar as Memórias à opera bufa: “Tutto nel mondo è burla” -, cantam Falstaff e o coro, para resumir as confusões e peripécias no final da ópera de Verdi. 'Tutto nel mondo è burla', parece dizer o narrador das Memórias de um sargento de milícias, romance que tem traços de ópera bufa." (Id., Ibid., p.80).

Pensando de modo mais detalhado nesse relativo silêncio musical na Dialética da Malandragem é que se estabeleceu o objetivo deste ensaio: partir da dialética da ordem e da desordem ("dialética da malandragem") conforme proposta por Antonio Candido (1970) e pensar de que modo a música participa dos deslizamentos dos personagens entre os dois polos. Usando a metáfora musical do tema e variações ${ }^{35}$, partimos da "dialética da ordem e da desordem", tema oferecido por Antonio Candido, propondo variações que tratam da ordem e da desordem a partir de um viés musical.

A simples retomada do texto de Antonio Candido (1970), pela sua fecundidade e relevância analítica para a literatura, já seria uma possível justificativa para o presente ensaio. No entanto, a preocupação de escutar a rica paisagem sonora ${ }^{36}$ descrita pelo livro de Manuel Antônio de Almeida não deve ser vista como tarefa de menor importância. Preocupação similar pode ser encontrada no interesse manifestado por pesquisadores que, sobretudo a partir dos anos 1990, se utilizaram da música como fonte significativa de suas pesquisas ${ }^{37}$. Além disso, analisar o livro a partir da dialética da ordem e da desordem nos pareceu fornecer pistas para pensarmos sobre a visão que o autor tinha da música, mapear a situação de parte do universo musical naqueles tempos e, por fim, elaborar elementos para uma história

\footnotetext{
${ }^{35}$ Forma musical na qual um tema é repetido várias vezes com modificações variadas.

${ }^{36} \mathrm{O}$ conceito de paisagem sonora está relacionado às pesquisas de Murray Shafer, pesquisador canadense que define o conceito como: "O ambiente sonoro. Tecnicamente, qualquer porção do ambiente sonoro visto como um campo de estudos. O termo pode referir-se a ambientes reais ou a construções abstratas, como composições musicais e montagens de fitas, em particular quando consideradas como um ambiente" (SCHAFER, 2001, p. 266).

${ }^{37}$ Segundo o pesquisador José Geraldo Vinci de Moraes é possível identificar um ponto de inflexão nos trabalhos sobre música a partir dos anos 1990. Apesar de certa "surdez" inicial dos historiadores, com o tempo "[...] inúmeros trabalhos têm surgido ampliando o horizonte historiográfico e apontando a direção de um campo específico" (MORAES e SALIBA, 2010, p. 20). Nesse sentido, o uso de novas fontes de pesquisa, como a música, tem se mostrado tendência significativa. Cf. José Ramos Tinhorão: Música Popular no Romance Brasileiro.Volume 1 (2000) e José Miguel Wisnik, Machado Maxixe: o caso Pestana (2003).
} 
da música e dos músicos. Em suma, nossa intenção por aqui é também perscrutar o papel da música no trabalho de Manuel Antônio da Almeida como um elemento de construção e representação de valores.

O argumento central do presente ensaio é o de que a música pode ser percebida como um elemento que acompanha de perto e até mesmo reforça a dialética da ordem e da desordem, conforme defendida por Antonio Candido. Partimos do principio de que existem dois polos, um positivo, a ordem, e um negativo, a desordem, que atraem Leonardo, personagem central, e o fazem transitar entre os dois hemisférios por meio das pressões e relações sociais. Desse modo, identificamos que na narrativa de Manuel Antônio de Almeida a música funciona como uma espécie de vetor que favorece esse trânsito. Esse movimento pode ser facilmente percebido quando se relacionam os acontecimentos musicais às várias situações nas quais os personagens transitam entre esses hemisférios. É possível até identificar uma certa tendência predominante da música como facilitadora dos deslizes dos personagens em direção à desordem. De modo mais especifico, é possível associar alguns gêneros musicais, ou modos de executar a música, a cada um desses hemisférios como, por exemplo, o minuete que representaria a ordem enquanto a modinha a desordem. Por fim, mas não menos importante, esse olhar mais sensível ao fenômeno musical permitiu vislumbrar em Manuel Antônio de Almeida certa simpatia pelos gêneros musicais associados à desordem, ainda mais do que a ausência de juízos de valor atribuída ao autor das Memórias pelos trabalhos aqui mencionados. Nesse sentido, parece que Maneco acabou antecipando a percepção manifestada por Machado de Assis do caráter postiço da cultura erudita no Brasil, conforme analisou com muita argúcia José Miguel Wisnik (2003).

\section{ENREDO}

A história das Memórias de um Sargento de Milícias é bastante conhecida. Pode-se dizer que, em linhas gerais, o livro apresenta uma sucessão de episódios, cenas e tipos sociais que orbitam o universo carioca no tempo do Rei D. João VI (1808-1821), ocasião em que a antiga colônia foi alçada à condição de Reino Unido. A narrativa apresenta as aventuras e desventuras de Leonardo desde o momento em que seus pais - Leonardo Pataca e Maria da Hortaliça - se conheceram em um navio vindo de Portugal, passando pelas peripécias e travessuras da infância, os amores e as diabruras da maioridade até culminar com a sua promoção a sargento de milícias e seu casamento com Luisinha no último capítulo do livro. O livro é narrado em primeira pessoa e tem uma série de personagens arquetípicos que acompanham a trajetória de Leonardo, a qual é marcada por episódios pitorescos e cômicos cujo pano de fundo muitas vezes são festas e comemorações populares dos estratos médios da cidade do Rio de Janeiro.

A recorrência de referências musicais ao longo da história permite que mesmo em uma leitura despretensiosa a presença da música no livro de Manuel Antônio de Almeida seja facilmente percebida. Essas referências aparecem em praticamente toda a narrativa: em episódios cômicos; em partes descritivas 
dos costumes populares, das práticas religiosas e profanas; em situações-chave do romance; e também em partes que poderíamos chamar de "românticas" (como, por exemplo, quando Leonardo se enamora por Vidinha no capítulo XX).

A partir do levantamento das passagens relacionadas à música, foi possível identificar que termos como modinha, viola, fado, minuete e machete são citados 19, 16, 16, 5 e 4 vezes respectivamente. Esse processo de levantamento pode ser acompanhado por meio da Tabela 1, em que são indicadas, além do capítulo em que ocorrem, as referências musicais trazidas pelo romance, além do papel da música naquele trecho e a participação dela dentro da dialética da malandragem segundo a teorização de Antonio Candido.

Tabela 1

Referências musicais nas Memórias de um Sargento de Milícias

\begin{tabular}{|c|c|c|c|c|}
\hline Capítulo & Págs. * & Início da citação & Referência musical & $\begin{array}{l}\text { Papel da } \\
\text { música ** }\end{array}$ \\
\hline $\begin{array}{c}\text { ' } \\
\text { Origem, nascimento e batismo }\end{array}$ & $13-14$ & "Já se sabe que houve nesse dia função [...]" & $\begin{array}{c}\begin{array}{c}\text { função; desafio; fado; rabeca; minuete da corte; viola; machete; } \\
\text { viola; modinha pátria; texto de uma modinha. }\end{array} \\
\end{array}$ & $0 \rightarrow 0$ \\
\hline $\begin{array}{c}V \\
\text { ovidigal }\end{array}$ & 25 & "Quando algum dos potuscos daquele tempo [...]" & "Lugar" social da viola & $0 \rightarrow 0$ \\
\hline $\begin{array}{c}\mathrm{VI} \\
\text { Primeira noite fora de casa }\end{array}$ & 28-29 & "Dai a pouco começou o fado. [...]" & fado; viola; fado (descrição); compasso da música & $0 \rightarrow 0$ \\
\hline $\begin{array}{c}\text { XIII } \\
\text { Mudança de vida } \\
\end{array}$ & 48 e 49 & \begin{tabular}{|c|} 
"Foi em consequência procurar aquele sacristão da sé que dançara \\
o minuete na festa do batizado [...]"
\end{tabular} & minuete e missa cantada & $0 \rightarrow 0$ \\
\hline $\begin{array}{c}\text { XIV } \\
\text { Nova vingança e seu resultado }\end{array}$ & 51 & $\begin{array}{l}\text { "Dispuseram-se as coisas; postou-se a música de barbeiros na porta } \\
\text { da igreja; [...]" }\end{array}$ & música de barbeiros & $\cdots$ \\
\hline $\begin{array}{c}\text { XV } \\
\text { Estralada }\end{array}$ & \begin{tabular}{|c|}
$54,55 e$ \\
56
\end{tabular} & "E começou a cantarolar o estribilho de uma modinha [...]" & estribilho de uma modinha; modinhas; tirana; viola & $0 \rightarrow 0$ \\
\hline $\begin{array}{c}\text { XVII } \\
\text { D. Maria } \\
\end{array}$ & $59-60$ & $\begin{array}{l}\text { "Um dia de procissäo foi sempre nesta cidade um dia de grande } \\
\text { festa [...]". }\end{array}$ & coretos; procissão dos ourives; rancho das Baianas & $\cdots$ \\
\hline $\begin{array}{c}\text { XIX } \\
\text { Domingo do Espirito Santo }\end{array}$ & $67 \cdot 8$ & $\begin{array}{l}\text { "Cada um dos meninos levava um instrumento pastoril em que } \\
\text { tocavam, pandeiro, machete e tamboril [...]" }\end{array}$ & $\begin{array}{l}\text { instrumento postoril; ; pandeio; machete; tamboril; música de } \\
\text { barbeiros }\end{array}$ & $\cdots$ \\
\hline $\begin{array}{c}x X \\
\text { o fogo no Campo } \\
\end{array}$ & 70 & $\begin{array}{c}\text { "Grande parte do Campo estava já coberta daqueles ranchos } \\
\text { sentados em esteiras }[. .] "\end{array}$ & modinha; guitarra; viola; termo originalidade & $\cdots$ \\
\hline $\begin{array}{c}\text { XXIV A } \\
\text { Comadre em exercicio }\end{array}$ & 78 & "A primeira coisa a que o Leonardo-pataca providenciou foi $[[-$.$] "$ & sino & $\cdots$ \\
\hline $\begin{array}{c}\mathrm{XXX} \\
\text { Remédio aos males } \\
\end{array}$ & 98-9 & "-Nada, inda nẫo: Vidinha vai cantar uma modinha [....]" & títulos de modinhas & $0 \rightarrow 0$ \\
\hline $\begin{array}{c}x \times x y \\
\text { Novos amores } \\
\end{array}$ & $100-1$ & $\begin{array}{c}\text { "Uma delas já os leitores conhecem; é Vidinha, a cantora de } \\
\text { modinhas; era solteira [...] }\end{array}$ & modinha; responso; viola; texto de uma modinha & $0 \rightarrow D$ \\
\hline $\begin{array}{c}\text { xxXII } \\
\text { José Manuel triunfa } \\
\end{array}$ & 102 & $\begin{array}{c}\text { "A comadre correra toda a cidade }[. . .] \text { regalando-se a ouvir } \\
\text { modinhas }[\ldots]^{*}\end{array}$ & modinha & D \\
\hline $\begin{array}{c}\text { Xxxıv } \\
\text { Malsinaçào }\end{array}$ & 111 & "Um dia forjaram uma patuscada semelhante $[\ldots] "$ & encordoar a viola & D \\
\hline $\begin{array}{c}\text { XLII } \\
\text { OGranadeiro }\end{array}$ & 131 e 132 & $\begin{array}{c}\text { "Os gaiatos e suciantes da cidade, a quem o major Vidigal dava } \\
\text { constantemente caça [...]" }\end{array}$ & fado, estribilho, cantiga, texto do "Papai lelê seculorum" & $0 \rightarrow 0$ \\
\hline $\begin{array}{c}\text { XLIII } \\
\text { Novas diabruras } \\
\end{array}$ & 134 e 138 & $\begin{array}{l}\text { "Havia um endiabrado patusco que era o tipo perfeito dos } \\
\text { capadócios daquele tempo [...] }\end{array}$ & viola, modinhas e fado & $0 \rightarrow 0$ \\
\hline & & & & \\
\hline \multicolumn{4}{|c|}{.$^{*}$ As páginas indicadas sorrespondem à edição indicada na bibligrafia (ALMEIDA, 1995) " ${ }^{\circ} \mathrm{Q}$ : ordem e D: desordem. Sf (CANDIDQ, 1970} & \\
\hline
\end{tabular}

\section{A FORTUNA CRÍTICA DAS MEMÓRIAS}

Com efeito, embora a música seja um elemento marcante nas Memórias, ela nunca foi pensada pela crítica como um aspecto estrutural da obra. Geralmente, a música é associada à parte dos "costumes" e ajuda a reforçar o caráter de "protorrealismo" atribuído à obra pelas análises que tem no trabalho de José Veríssimo, de 1894, seu principal representante, corrente esta que marcou a primeira geração de crítica do romance.

Uma segunda geração analítica foi formada a partir do prefácio da edição de 1941, escrito por Mário de Andrade. Esse prefácio é pioneiro no levantamento de questões musicais. No texto, Mário de Andrade retomou aspectos biográficos da vida de Maneco, modo afetuoso como ele se referia à Manuel 
Antônio de Almeida, e traçou algumas relações com a vida do próprio Leonardo, que é apresentado como “bom e 'legítimo’ pícaro” (ANDRADE, 1941, p. 145). Com efeito, o texto de Mário de Andrade ficou mais conhecido por lançar luz sobre o aspecto picaresco das Memórias, aspecto que marcou toda uma geração crítica que relacionava a obra de Manuel Antonio de Almeida à novela de Lazarillo de Tormes de $1554^{38}$ e a outros anti-heróis da literatura romanesca.

Se por um lado, o prefácio de Mário de Andrade ficou mais conhecido por associar Memórias de um Sargento de Milícias ao pícaro romanesco, por outro, apontou diversas pistas sobre o papel da música no livro de Maneco, contribuição que foi praticamente ignorada pela crítica subsequente. Assim, mais do que afirmar o caráter picaresco das Memórias, Mário de Andrade destacou o aspecto das tradições folclóricas ${ }^{39}$ e da música na narrativa, afirmando ainda que Manuel Antônio de Almeida: "tinha em grau elevadíssimo a bossa do folclorista, e estava consciente disso pois confessa francamente, no livro, trazer entre a suas intenções a de fixar costumes. A todo instante a observação folclórica é decisiva, sem falha" (ANDRADE, 1941, p. 153).

Em 1970, Antonio Candido escreveu o texto que se tornou uma das principais referências para a análise das Memórias, A Dialética da Malandragem. Neste artigo, publicado na edição número oito da Revista do Instituto de Estudos Brasileiros, Antonio Candido criticava tanto a visão da tradição picaresca, quanto o papel de pioneiro do romance de costumes e do realismo atribuído à obra. De acordo com o autor, apesar do livro conter esses elementos, eles não são decisivos para a classificação do romance. Com efeito, na primeira parte do ensaio, Antonio Candido analisa e "desmonta" as leituras que buscaram classificar o livro como romance picaresco, apontando que ao contrário das histórias características desse gênero, escritas em primeira pessoa, o romance de Maneco é narrado em terceira pessoa. Além disso, Leonardo difere dos anti-heróis pícaros tradicionais, pois atravessa a história praticamente ileso das humilhações e rebaixamentos que moldam a tomada de consciência dos personagens do gênero. Portanto, apesar de conter características dos pícaros, Leonardo na verdade seria "o primeiro grande malandro que entra na novelística brasileira" (CANDIDO, 1970, p. 71), inserido na produção cômica e satírica do período Regencial, momento marcado pela caricatura política. Em seguida, Antonio Candido critica a visão de que as Memórias são um livro de aspecto documental e realista e justifica que, se por um lado, o livro se concentra nas faixas médias da população, por outro, ignora completamente a presença dos escravos na caracterização da sociedade carioca do Reinado.

Apesar da ausência de outras camadas sociais, Antonio Candido identifica um aspecto da realidade que estaria relacionado à opção formal de Maneco e que teria implicações no conteúdo do livro. Candido explica que, tal como a sociedade brasileira, a narrativa do livro opera em dois eixos, um da

\footnotetext{
${ }^{38}$ De autoria anônima, La vida de Lazarillo de Tormes y de sus fortunas y adversidades, título que recebeu à época, fez relativo sucesso ao se opor aos romances de cavalaria do período e foi escrito de maneira irônica e caricata para criticar a sociedade.

${ }^{39}$ Não custa lembrar que a pesquisa e o aproveitamento do folclore era uma das principais características do Romantismo. O que mais uma vez corrobora a ideia de que Memórias de um Sargento de Milícias não estaria assim tão distante dos cânones desse período da história da literatura.
} 
ordem e outro da desordem. É a partir desses eixos que se estabelece a dialética da malandragem ${ }^{40}$. Para Antonio Candido, o universo criado por Manuel Antônio é um mundo sem culpa e remorso, que tem na hipocrisia uma das suas marcas. Nesse universo há um baralhamento entre a ordem e a desordem, que seria uma síntese arquetípica, e não documental, da sociedade brasileira. Tal síntese seria caracterizada pelas muitas artimanhas usadas pelos personagens para atingirem seus objetivos, como por exemplo as relações de compadrio e as inúmeras associações por interesse. Daí a diferença com a produção literária do Romantismo na qual as dicotomias entre bem e mal eram claras e bem definidas ${ }^{41}$.

\begin{abstract}
Nisto e por tudo isto, as Memórias de um sargento de milícias contrastam com a ficção brasileira do tempo. Uma sociedade jovem, que procura disciplinar a irregularidade da sua seiva para se equiparar às velhas sociedades que lhe servem de modelo, desenvolve normalmente certos mecanismos ideais de contensão, que aparecem em todos os setores. No campo jurídico, normas rígidas e impecavelmente formuladas, criando a aparência e a ilusão de uma ordem regular que não existe e que por isso mesmo constitui o alvo ideal (CANDIDO, 1970, p. 85).
\end{abstract}

Em 1987, A Dialética da Malandragem foi objeto de uma análise crítica pormenorizada realizada por Roberto Schwarz no texto Pressupostos, salvo engano, de a Dialética da Malandragem. Nesse artigo, Schwarz reconheceu o esforço, até então inédito, do trabalho de Antonio Candido e seu ato crítico que reunia "uma análise de composição, que renova a leitura do romance e o valoriza extraordinariamente; uma síntese original de conhecimentos dispersos a respeito do Brasil" e que "descobre uma grande linha que não figurava na historiografia literária do país" (SCHWARZ, 1987, p. 130).

$\mathrm{O}$ autor destacou ainda a originalidade da tese de que a alternância da ordem e da desordem como própria forma do romance seja profundamente representativa do Brasil e que em momentos chave do romance a dialética da ordem e a desordem encontra equivalência simbólica como, por exemplo, na cena em que o Major Vidigal é surpreendido de farda e tamancos. No entanto, para Schwarz, ao salientar o jogo entre as estruturas literárias e históricas Antonio Candido acaba por dar um tratamento mais rigoroso à forma literária do que à realidade social: "Antonio Candido é estrito na construção crítica da forma e na descrição de sua pertinência social, mas no plano da história prefere uma construção mais solta" (SCHWARZ, 1987, p. 150).

Não é objetivo do presente ensaio fazer uma revisão bibliográfica das Memórias de um Sargento de Milicias, mas reconhecer que em seu texto Antonio Candido elaborou, apesar das possíveis limitações apontadas por Roberto Schwarz, uma excelente síntese que serve como ponto de partida para a análise da relação entre literatura e sociedade. A revisão crítica presente nos Pressupostos de Schwarz, por sua vez, parecem sugerir um aprofundamento nessas questões a partir do âmbito sociocultural, sem no entanto invalidar o brilhante trabalho de Antonio Candido, abrindo outras perspectivas de análise da obra de

\footnotetext{
${ }^{40}$ Conforme foi tratado na introdução do presente trabalho.

${ }^{41}$ Como no caso de O Guarani, por exemplo.
} 
Manuel Antônio de Almeida ${ }^{42}$. Foi essa relevância, do texto de Antonio Candido, que motivou abordar a questão musical no presente ensaio tendo como base de inspiração a dialética da ordem e da desordem conforme pensadas pelo crítico literário. Nesse sentido, a leitura do prefácio escrito por Mário de Andrade também se mostrou fundamental para tratar dessa questão.

O texto de Mário de Andrade, além de sua relevância para a crítica literária, traz também pontos interessantes no que diz respeito à forte presença da música no romance de Manuel Antônio de Almeida. Isto se deve, muito provavelmente, aos interesses multifacetados de Andrade, em particular sua significativa relação com a música e suas reflexões e pesquisas sobre esse tema. Além da interessante especulação sobre possíveis relações do pai de Maneco com a música, Mário de Andrade revelou ainda em seu prefácio à edição de 1941 das Memórias inúmeros outros elementos significativos. Para ele, Manuel Antônio de Almeida “enumera instrumentos, descreve danças, conta o que era a 'música de barbeiros', nomeia as modinhas mais populares do tempo" (ANDRADE, 2002, p. 150). Ele destacou também que o romance chega a citar o título de duas modinhas: Se os meus suspiros pudessem e Quando as glórias que en gozei. Foi devido a esse olhar musical que Mário de Andrade conseguiu identificar em Maneco "a bossa do folclorista" citada pouco acima. Além disso, o fato de o pesquisador ter publicado Quando as glórias que gozei [sic] em seu livro Modinhas imperiais, ajuda a entender seu interesse pelas informações musicais trazidas pelo romance. Datar, estudar e fazer reviver esse material estava na pauta do musicólogo paulista.

Em seu prefácio, Mário de Andrade ainda manifestou surpresa por ter deixado escapar “documentação tão preciosa” quando escreveu seu estudo sobre As origens do fado, referindo-se sobretudo ao primeiro capítulo do romance, à cena do batizado (ANDRADE, 2002, p. 150-1). Por meio das inúmeras referências ao termo fado encontradas no texto das Memórias, Andrade aproveitou para defender que nos últimos tempos coloniais o "desafio era costume de portugueses e o fado privativo de brasileiros" (Id., Ibid., p. 151). O musicólogo paulista ainda se encantou ao identificar no texto das Memórias algumas referências ao lundu. Esse conjunto de referências musicais ajudaram-no a embasar sua discordância em relação à uma concepção da época que defendia que o lundu só se transformaria em fado em Portugal.

Apesar de notar e chamar a atenção dos leitores sobre a "ausência quase total de contribuição negra" no romance (Id., Ibid., p. 152), Mário de Andrade observou que o texto de Almeida ajudou-o a provar mais coisas, como por exemplo o fato de que as práticas religiosas dos negros coexistiam com "princípios urbanizados de religiosidade supersticiosa, de base ameríndia” (Id., Ibid., p. 153). Em resumo, Mário de Andrade fez avançar a ciência musicológica daqueles tempos apropriando-se do romance de Manuel Antônio de Almeida como fonte de grande qualidade. Qualidade que o pesquisador reconheceu acima de tudo na grande capacidade de análise humana do escritor carioca (Id., Ibid., p. 154).

\footnotetext{
${ }^{42}$ Edu Teruki Otsuka, professor do Departamento de Teoria Literária da FFLCH-USP, abordou as Memórias de um Sargento de Milícias usando como ponto de partida o diagrama da ordem e da desordem da Dialética da Malandragem de Antonio Candido para analisar as rixas e as relações de compadrio como elemento das práticas sociais e culturais do país. Cf. (OTSUKA, 2007).
} 
Com igual interesse e entusiasmo o jornalista e pesquisador José Ramos Tinhorão se aproveitou das Memórias em seu livro $A$ música popular no romance brasileiro, mais particularmente em seu primeiro volume, dedicado aos séculos XVIII e XIX. Em seu livro, Tinhorão destaca uma pretensão sua que parece ter relevância enquanto justificativa para este ensaio. O autor defende, logo no início do texto, que seu livro é "um livro único, no sentido de não se conhecer antecedentes na bibliografia de qualquer país" tanto pelo tema quanto pela abordagem (TINHORÃO, 2000, p. 9). Esse dado reforça a constatação feita acima sobre o silêncio em relação à presença da música na literatura. Apesar de não termos partido de um levantamento exaustivo prévio dessa questão, tal dado reforça a expetativa de contribuição de nosso ensaio.

Um primeiro dado apontado por Tinhorão revela o modo singular como o pesquisador vê o livro de Almeida bem como esclarece um pouco de suas pretensões com o estudo das relações entre literatura e música. Segundo Tinhorão, depois de $A$ Moreninha, romance de 1844, foi preciso esperar até Manuel Antônio de Almeida, em 1852, com seu livro Memórias de um Sargento de Milícias, para ver retomado "o tema da música popular no âmbito do povo propriamente dito" (TINHORÃO, 2000, p. 109). Isto porque, segundo o pesquisador, em muitas obras de José de Alencar e de Machado de Assis "as referências vão se restringir às danças de salão de origem europeia” (Id., Ibid., p. 109). O caso de Machado de Assis, pelo menos, é mais complexo. A visão deste escritor sobre o universo da arte muda em favor de um olhar mais perspicaz em relação à fragilidade do lugar ocupado pela arte erudita no Brasil. Mas deixemos por ora esse ponto, retomando-o logo adiante. Ainda dentro do propósito de encontrar para as Memórias um lugar singular, Tinhorão defendeu que Manuel Antônio de Almeida é o autor que pela primeira vez "admitiu assumir enquanto narrador a condução das peripécias de sua história do ponto de vista do povo”. O pesquisador reforçou seu argumento lembrando que talvez Almeida fosse o único escritor de sua época a não expressar uma visão de classe dominante (Id., Ibid., p. 113). Nesse ponto já se nota claramente seu diálogo com o texto de Antonio Candido (1970), trabalho este que consta na bibliografia de seu livro.

De um ponto de vista mais estritamente musical, Tinhorão destacou o uso repetido no romance da palavra fado para designar dança e canto (10 vezes em toda a narrativa). Chamou também a atenção para o fato de que essa forte presença no texto de Almeida acabou levando muitos musicólogos e folcloristas, entre os quais Mário de Andrade, a acreditarem que o fado português tivesse origem na dança brasileira de mesmo nome (Id., Ibid., p. 119). Respondendo a esses autores e, assim como eles, se valendo das Memórias como fonte significativa de pesquisa, Tinhorão esclareceu que, na primeira metade do século XIX, “fado [...] não era apenas uma dança que eventualmente incluía 'em certos compassos uma cantiga' [...], mas também o nome que se dava às brincadeiras ou funções populares que implicavam danças e cantorias” (Id., Ibid., p. 120). Sempre iluminado pelas referências musicais do romance, Tinhorão ainda destacou que "nesses fados não se dançavam e cantavam apenas fados, mas modinhas sentimentais brasileiras, modas portuguesas [...], tiranas", como também pequenas dramatizações como o fado com 
"estribilho nas cantigas: Papai lelê, seculorum”, criado pelo povo como represália as repressões do major Vidigal (Id., Ibid., p. 122). Apesar da riqueza dessas informações, para Tinhorão, Manuel Antônio de Almeida não se limitou à representação de fados. As memórias "refletem também de maneira clara a popularidade do gênero de canção mais divulgado e mais cultivado em todos os centros urbanos do Brasil desde o século XVIII: a modinha” (Id., Ibid., p. 126). É justamente em relação a este gênero, tido como fundamento da música popular, que o romance traz, sempre segundo Tinhorão, as melhores informações, especialmente ao citar textualmente os títulos “das verdadeiras modinhas brasileiras” (Id., Ibid., p. 127).

Tinhorão conseguiu tirar do romance mais uma última informação para embasar uma posição sua: pelo menos até a segunda década do século XIX, “O violão ainda não tinha feito sua entrada como instrumento de acompanhamento de música popular, continuando a predominar em caráter praticamente exclusivo o emprego da viola entre as pessoas brancas e mestiças das camadas do povo e da baixa classe média” (Id., Ibid., p. 127). É o que o pesquisador é levado a concluir tendo por base a ausência no romance do termo "violão" e das inúmeras referências ao termo "viola", nada menos do que 16 vezes, como indicado acima.

\section{DO MINUETO À ALGAZARRA: A MÚSICA NA CERIMÔNIA DE BATISMO}

Já no primeiro capítulo do livro, temos um exemplo do funcionamento da dialética da ordem e da desordem e como ambas convivem no universo narrativo das Memórias de um Sargento de Milícias. O episódio, não por acaso, ocorre durante uma cerimônia religiosa, o batizado de Leonardo. Ao inicio da comemoração, Leonardo Pataca - nesse momento do livro um dos vetores da ordem segundo definição de Antonio Candido - para manter os ares aristocráticos da festa tentou impor aos presentes um lento e imponente "minuete da corte", apesar das dificuldades, como a falta de pares e os guinchos e esperneios de Leonardinho que faziam o Compadre perder os compassos da dança. Em seguida, porém, "o Leonardo, instado pelas senhoras, decidiu-se a romper a parte lírica do divertimento". Ele então se sentou em um banquinho e "inspirado pelas saudades da terra natal" começa a tocar uma modinha. O episódio é descrito a partir da aparência cômica que a visão de Leonardo tocando a saudosa canção propiciava:

Fazia um belo efeito cômico vê-lo, em trajes do ofício, de casaca, calção e espadim, acompanhando com um monótono zunzum nas cordas do instrumento o garganteado de uma modinha pátria (ALMEIDA, 1995, p. 13).

A comicidade citada pelo narrador se dá pela imagem de Leonardo todo paramentado com os trajes de ofício, sentado em um banquinho tocando viola. Esta breve descrição serve como exemplo da maneira como os hemisférios da ordem e da desordem são fundidos de maneira simbólica e mostram o 
"balanceio caprichoso" entre eles de maneira similar à proposta de Antonio Candido na Dialética da Malandragem $^{43}$.

Para além de reduzir Leonardo à imagem viva dos dois hemisférios da ordem e da desordem, é justamente após a modinha que o batizado descamba para a balbúrdia e só não desce a níveis mais baixos, em direção à completa desordem, pelo risco da aparição do Major Vidigal:

O canto do Leonardo foi o derradeiro toque de rebate para esquentar-se a brincadeira, foi o adeus às cerimônias. Tudo dá em diante foi burburinho, que depressa passou à gritaria, e ainda mais depressa à algazarra, e não foi ainda mais adiante porque de vez em quando viam-se passar através das rótulas da porta e janelas umas certas figuras que denunciavam que o Vidigal andava perto (ALMEIDA, 1995, p. 14).

Neste episódio é possível identificar um notável exemplo do papel que a música, principalmente a modinha, parece ter como vetor da desordem. Foi justamente a cantoria de Leonardo que deu adeus às cerimonias introduzindo o burburinho, a gritaria e a algazarra. As palavras usadas por Maneco (burburinho, gritaria e algazarra) não poderiam ser mais precisas para delimitar o aspecto da desordem, uma vez que, pela própria semântica, tais termos estão diretamente relacionados à confusão, ao ruído e à própria desordem. Desordem esta que só poderia ser refreada pela ameaça da possível visita do Major Vidigal, famoso estraga prazeres e símbolo máximo da ordem segundo diagrama estabelecido por Antonio Candido.

Portanto, já no primeiro capítulo se notam os elementos que compõem a dialética musical da ordem e da desordem, por meio da aparência de Leonardo tocando viola, e também na maneira pela qual a modinha se configura como um "passaporte" para a desordem.

\section{PASSAPORTE PARA A DESORDEM}

Conforme já se havia antecipado, a música acaba funcionando como uma espécie de vetor que conduz ou, no mínimo, favorece o trânsito das personagens da ordem para a desordem, nessa condição se encontram as passagens mais significativas do romance. Outro exemplo pode ser percebido no capítulo $\mathrm{V}, \mathrm{O}$ Vidigal, no qual se fica sabendo que "quando algum dos patuscos daquele tempo [...] era surpreendido de noite de capote sobre os ombros e viola a tiracolo, caminhando em busca de súcia [...]" era cadeia na certa. Carregar uma viola a tiracolo era justificativa para a inexorável intervenção do major Vidigal. O único remédio que restava ao “malandro”, segundo esclarece Maneco, era correr (ALMEIDA, 1995, p. 25).

\footnotetext{
43 Antônio Candido usou como exemplo do "balanceio caprichoso" da ordem e da desordem o episódio no qual o Major Vidigal recebe a inesperada visita das senhoras (capítulo XXIII). Pego de surpresa, ele é visto de farda e tamancos, segundo Antonio Candido, um símbolo da ética dos dois mundos reduzida a um personagem (CANDIDO, 1970, p.81.).
} 
No capítulo seguinte, Primeira noite fora de casa, o pequeno Leonardo fugindo, devido ao mau comportamento manifestado em sua estreia como sacristão, se junta a uma via-sacra na qual acaba conhecendo dois pequenos ciganos. Os dois meninos então o convidam a participar de uma festa no largo do Rossio, naquele tempo também chamado de campo dos Ciganos, onde moravam com sua gente. Tratava-se de uma celebração muito particular. Segundo descreve o autor, em um lado da sala se encontrava um oratório iluminado e cercado por velas. Apesar da atmosfera e da ornamentação religiosas, assim que os três meninos chegaram a casa, se iniciou o fado, nas palavras do autor, "essa dança tão voluptuosa, tão variada, que parece filha do mais apurado estudo da arte" (ALMEIDA, 1995, p. 28). Trata-se aqui da mesma referência musical comentada longamente por Mário de Andrade e José Ramos Tinhorão em seus trabalhos, ambos referidos anteriormente. Para além dos aspectos coreográficos - que envolvia rica movimentação, muito contato corporal entre os dançarinos, e ruídos típicos do bater de palmas e do sapateado -, Manuel Antônio explica ainda que, uma vez começado, o fado só terminava pela madrugada, quando não levava "de enfiada dias e noites seguidas e inteiras" (Id., Ibid., p. 29). Na passagem, o autor não explica se houve de fato uma parte religiosa nessa festividade; o fato é que, com ou sem ela, a música esteve presente durante todo o fado. Depois de assistir à festa, Leonardinho adormeceu junto aos seus companheiros, "todos embalados pela viola e pelo sapateado" (Id., Ibid., p. 29).

Na próxima sequência ouvem-se a modinha e a tirana como trilha sonora de uma "estralada" ${ }^{4}$ termo que dá nome ao capítulo XV - ocasião armada por Leonardo pai para se vingar da Cigana que o havia trocado pelo mestre-de-cerimônia. A ideia do despeitado amante foi contratar um valentão, o Chico-Juca, para se infiltrar na festa de aniversário da Cigana e, armada a desordem, fugir antes que chegasse o major Vidigal, este já advertido pelo amante desprezado. Leonardo até tentou dissuadir a Cigana de seu novo romance, porém depois de negar e rir-se de tal pedido ela "começou a cantarolar o estribilho de uma modinha" (Id., Ibid., p. 54). No trecho o romancista descreve a "função" armada para a celebração do aniversário como um misto de "viola, modinhas, fado [e] algazarra" (Id., Ibid., p. 54). A própria entrada em cena do Chico-Juca só aconteceu quando “já se tinha cantado meia dúzia de modinhas e dançado por algum tempo a tirana", estratégia talvez arquitetada pelo Leonardo (ou pelo próprio autor) para garantir que os presentes já apresentassem a necessária predisposição para a desordem. E foi justamente um instrumento de música - feito ressoar de modo nada convencional - que deu o sinal para a completa confusão. Já dentro da festa, Chico-Juca passou "mais de meia hora a dirigir graçolas das suas a uma moça que ele bem sabia que era coisa do rapaz que estava tocando". Não podendo mais resistir à provocação, o musicista replicou. Ele mal tinha ditos suas palavras de reprovação "quando o Chico-Juca, arrancando-lhe a viola da mão, bateu-lhe com ela em cheio sobre a cabeça" (Id., Ibid., p. 56). Daí a coisa descambou para a confusão agravada pelas cabeçadas e pontapés desferidos pelo valentão nos

${ }^{44}$ Estralada: confusão, desordem. 
convidados. Como havia sido arranjado, no auge da estralada, Chico-Juca saindo pela porta desapareceu. Esse foi o momento da grande pausa: os convidados apenas viram o major Vidigal, ficaram aterrados. O silêncio era a ocasião propícia para o retorno da ordem.

Finalmente, é preciso dar especial destaque para o momento em que Leonardo conhece Vidinha; momento que, segundo Antonio Candido, o leva ao polo extremo da desordem, funcionando como uma espécie de ponto de inflexão em sua trajetória quase sempre socorrida pelo acaso. É nesse trecho que a presença de uma arte tão sestrosa se faz mais presente. Tal passagem ocorre no capítulo XXX, Remédio aos males, que se inicia com a fuga de Leonardo de casa, depois de uma forte discussão com o pai. A espada com que este ameaçou o filho representou elemento análogo ao pontapé do início da história, recurso que serviu para dar força à cena. Depois de muito perambular, Leonardo foi dar "lá pelas bandas dos Cajueiros", onde acabou reencontrando o antigo colega sacristão mirim que participava de uma súcia. Depois de reconhecer o amigo de aventuras passadas, este o introduziu ao resto do bando, do qual fazia parte Vidinha, "mulatinha de 18 e 20 anos, de altura regular, [...] cintura fina e pés pequeninos; tinha os olhos muito pretos e vivos, os lábios grossos e úmidos, os dentes alvíssimos, a fala era um pouco descansada, doce e afinada" (ALMEIDA, 1995, p. 98). O encantamento de Leonardo por ela começa justamente quando, antes de partir a trupe, Vidinha canta uma modinha, escolhida depois de uma breve disputa entre diferentes títulos, sendo escolhida, por fim, Se os meus suspiros pudessem (Id., Ibid., p. 99). É nesse momento que o pendor de Leonardo para a ordem oferecido por uma eventual união com Luisinha, neta de D. Maria, começa a ir por terra. Nas palavras do autor:

[o] Leonardo, que talvez hereditariamente tinha queda para aquelas coisas, ouviu boquiaberto a modinha, e tal impressão lhe causou, que depois disso nunca mais tirou os olhos de cima da cantora. A modinha foi aplaudida como cumpria. Levantaram-se então, arrumaram tudo o que tinham levado em cestos, e puseram-se a caminho, acompanhando o Leonardo o farrancho (Id., Ibid., p. 99).

Não tendo para onde ir, depois da briga com o pai, ainda que titubeando inicialmente, Leonardo aceitou o convite para acompanhar a trupe e se hospedar entre eles em uma casa na Rua da Vala. O grupo era composto por duas irmãs, ambas viúvas, uma delas com três filhas e a outra com dois filhos. Vidinha, a cantora de modinhas, era uma dessas filhas, a outra era a namorada do amigo de Leonardo. Se o protagonista antes não conseguia tirar da cabeça Luisinha e seu rival José Manuel, “agora não via senão os olhos negros e brilhantes, e os alvos dentes de Vidinha; não ouvia senão o eco da modinha que ela cantara" (Id., Ibid., p. 100). O encantamento levou Leonardo a pedir nova apresentação. As velhas então acabaram por fazer a escolha de outra modinha, cujo texto dizia "Duros ferros me prenderam/no momento de te ver;/Agora quero quebrá-los,/É tarde não pode ser.” (Id., Ibid., p. 101). E nesse ponto se completa o percurso de Leonardo, segundo descreve Manuel Antônio. Depois que Vidinha tomou a viola e interpretou tão inspirada composição, "este último passo acabou de desorientar completamente o Leonardo" (Id., Ibid., p. 101). Essa seria a trilha sonora de sua vida de vadiagem. 
Assim como Leonardo Pataca, o pai, que ao tocar uma modinha também abriu espaço para a desordem, agora foi Vidinha, a tocadora de modinhas, quem puxou Leonardo filho para o mesmo hemisfério da dialética proposta por Antonio Candido: "É durante a fase dos amores com Vidinha, ou logo após, que Leonardo se mete nas encrencas mais sérias e pitorescas, como que libertado dos projetos respeitáveis que o padrinho e a madrinha tinham traçado para a sua vida" (CANDIDO, 1970, p.79).

A vida de agregado e completo vadio, porém, não durou muito tempo. Vidinha na verdade era disputada por dois dos primos citados. Apelando para a concorrência desleal, acabaram eles armando um tipo de malsinação ${ }^{45}$ para se livrarem do Leonardo. No capítulo XXXIV, organizam os moradores da casa onde Leonardo era agregado uma nova patuscada, como aquela dos Cajueiros no dia da briga com o pai. Como não poderia deixar de ser, não poderia faltar a música e para tal Vidinha "mandou encordoar de novo sua viola”. Quando já se encontravam no local, apenas se preparavam para o almoço, irrompeu “a figura alta, magra, severa e sarcástica do nosso célebre major Vidigal” (ALMEIDA, 1995, p. 111). Este então deu ordem a um de seus granadeiros para que levasse o Leonardo. Vidinha desatou a chorar, exclamando: “- Foi malsinação!” (Id., Ibid., p. 112).

Apesar de protagonizar uma fuga espetacular logo após sua captura, Leonardo foi recuperado logo depois pelo temido major Vidigal. Isso aconteceu em seguida a um frustrado e breve período de trabalho na ucharia ${ }^{46}$ Real onde protagonizou, ainda que involuntariamente, um episódio desastroso envolvendo a mulher do toma-largura ${ }^{47}$.

O infeliz episódio acabou por oferecer uma interrupção na trajetória de Leonardo dentro do território da desordem. Por meio da intervenção do major, ele acabou sendo alçado, não sem novos deslizes, à esfera da ordem. Nesse sentido, a vingança do Vidigal não poderia ser mais eficaz. Depois de prender Leonardo devido ao episódio da ucharia, por meio de uma manobra, o major fez o Leonardo "sentar praça no Regimento Novo". A vida de nosso herói "na escola de vadiação e peraltismo" capacitou-o como um ótimo oficial, conhecedor que era de "todas as manhas do ofício" (Id., Ibid., p. 131). Porém, como já se tinha antecipado, não demorou muito para que Leonardo tivesse o seu primeiro tropeço, descambando, ao som da música, mais uma vez dentro da desordem. Isso se deu durante cerimônia muito singular.

Os gaiatos e suciantes da cidade, a quem o major Vidigal dava constantemente caça, lembraram-se de imortalizar as suas façanhas por qualquer meio, e inventaram um fado com o seguinte estribilho nas cantigas:

Papai lelê, seculorum. (Id., Ibid.,p. 131)

Tratava-se nada mais nada menos do que o velório do próprio Vidigal, que era representado amortalhado no meio da sala, cabendo aos demais participantes a incumbência de cantar-lhe cantigas

\footnotetext{
${ }^{45}$ Malsinação: ação ou efeito de malsinar; denúncia, acusação, delação.

${ }^{46}$ Ucharia: despensa da Casa Real

${ }^{47}$ Toma-Largura: termo usado para designar os funcionários do Paço Imperial que trabalhavam em serviços subalternos.
} 
alusivas que terminavam sempre com o estribilho acima indicado. Certa vez, organizou-se o gracejo em uma casa no morro da Conceição. Ao Leonardo coube o honroso papel de representar o próprio major, desempenhando sua função de modo muito convincente em meio ao "zunzum das violas e a toada das cantigas" na casa onde "fervia dentro o fado rigoroso" (Id., Ibid., p. 132). Moral da história: agente da ordem que havia se tornado, por meio do mesmo vetor, a música, Leonardo foi levado pela arte cheia de manha novamente para o conhecido território da desordem.

Pela sua esperteza, o major conseguiu frustrar o retorno de Leonardo à vadiagem, fato que deixou o jovem oficial bastante acabrunhado. Cabisbaixo e pensativo, como se manteve após o episódio frustrado, não perdeu a ocasião de se meter em Novas diabruras, que a ele foram oferecidas no capítulo XLIII. Desta vez, porém, coube a ele papel secundário, ofuscado agora pelo talento de um novo personagem. Fala-se aqui de Teotônio, protagonista de uma das peças mais hilárias pregadas no major. Segundo Manuel Antônio o “endiabrado patusco [...] era o tipo perfeito dos capadócios daquele tempo, sobre quem há muitos meses andava o major de olhos abertos, sem que entretanto tivesse achado ocasião de pilhá-lo" (Id., Ibid., p. 134). O papel de Leonardo nessa patuscada é justamente o de ter dado cobertura para que Teotônio pudesse fugir da festa de batizado de seu meio irmão, ocasião em que o Vidigal procurava capturá-lo. Isto tudo em conluio com os demais convidados presentes, que nutriam a mesma "simpatia" pelo major. Se antecipamos o final desse acontecimento é para justamente poder nos concentrar no perfil de Teotônio que é o que nos interessa mais neste ponto. Segundo se sabe dele, nas palavras do romancista,

Tocava viola e cantava muito bem modinhas, dançava o fado com grande perfeição, falava lingua de negro, e nela cantava admiravelmente, fingia-se aleijado de qualquer parte do corpo com muita naturalidade, arremedava perfeitamente a fala dos meninos da roça, sabia milhares de adivinhações, e finalmente, - eis aqui o seu mais raro talento, - sabia com rara perfeição fazer uma variedade infinita de caretas que ninguém era capaz de imitar. (Id., Ibid., p. 134)

Talvez abençoado pela musa das modinhas, que lhe dava uma espécie de passaporte livre, tinha ele capacidade semelhante a Orfeu que, pela força de sua lira, podia transitar livremente entre terra e inferno em busca de sua Eurídice. Tal como o mítico herói grego, Teotônio tinha a capacidade de transitar entre mundos diversos, aqui mais especificamente entre ordem e desordem. Ao descrever o singular perfil do personagem, Maneco lembrou que Teotônio “[o]rdinariamente amanhecia em numa súcia que começara na véspera, uns anos, por exemplo; ao sair daí ia para um batizado; à noite tinha uma ceia de casamento" (Id., Ibid., p. 134). Pois é justamente a sua participação na festa de batizado do filho mais novo do Leonardo pai que vai descambar na desordem, na maior patuscada pregada ao major. Leonardo filho, então cabo da guarda, havia sido incumbido pelo Vidigal de dar o sinal para que ele e os demais granadeiros prendessem Teotônio na saída da festividade. Sendo um de seus principais talentos a 
imitação: este se fez passar por um corcunda-aleijado, passando com facilidade pelo major, enganandoo, "assobiando tranquilamente o estribilho de uma modinha" (Id., Ibid., p. 138).

\title{
INTERMEZZO
}

Nesta altura, parece oportuno destacar que apesar da profusão de exemplos em que a música ocupa papel estrutural - tal qual um vetor que favorece a passagem da ordem para a desordem - existem ainda outras tantas referências musicais no livro de Manuel Antônio de Almeida de natureza diversa. Algumas delas mostram-se neutras em relação à dialética proposta por Antonio Candido (1970), não obstante serem passagens significativas para o estudo musicológico. Um exemplo apontado por Mário de Andrade em seu prefácio (1941), citado anteriormente, encontra-se no capítulo XIV do romance, Nova vingança e seu resultado, quando Leonardo e seu amigo vingam-se do mestre-de-cerimônias que os havia repreendido por atos manifestados na estreia deles como pequenos sacristãos. A ambientação do capítulo é caracterizada pela presença de um grupo muito particular de músicos. Nas palavras do próprio autor:

\begin{abstract}
Dispuseram-se as coisas; postou-se a música de barbeiros na porta da igreja; andou tudo em rebuliço; às 9 horas começou a festa.

As festas naquele tempo eram feitas com tanta riqueza e com muito mais propriedade, a certos respeitos, do que as de hoje: tinham entretanto alguns lados cômicos; um deles era a música de barbeiros à porta. Não havia festa em que se passasse sem isso; era coisa reputada quase tão essencial como o sermão; o que valia porém é que nada havia mais fácil de arranjar-se; meia dúzia de aprendizes ou oficiais de barbeiro, ordinariamente negros, armados, este com um pistão desafinado, aquele com um trompa diabolicamente rouca, formavam uma orquestra desconcertada, porém estrondosa, que fazia as delícias dos que não cabiam ou não queriam estar dentro da igreja (ALMEIDA, 1995, p. 51).
\end{abstract}

A maneira perspicaz e cheia de intuição como Manuel Antônio registra a cena nos leva quase a ouvir esse gênero musical tão singular, a música de barbeiros ${ }^{48}$.

Ainda nessa direção poderia ser citado o capítulo XIX, Domingo do Espírito Santo, dedicado à descrição das Folias que aconteciam por ocasião das celebrações do Domingo do Espírito Santo. Nessa ocasião, segundo as palavras do autor do livro, "[c]ada um dos meninos levava um instrumento pastoril em que tocavam, pandeiro, machete e tamboril". Manuel Antônio ainda se dedicou a descrever a coreografia da festa, seus personagens, além de revelar a presença novamente da "fanhosa música de barbeiros" (Id., Ibid., p. 67). É digna de nota também a referência presente na letra cantada pelos pastores, na qual o Espírito Santo é chamado de "grande folião" (Id., Ibid., p. 68). Gesto que pode ser interpretado tanto como a personificação e deslizamento para o território da desordem até mesmo de um símbolo

\footnotetext{
${ }^{48}$ Esse tema deve ter sido objeto de grande interesse para Mário de Andrade. Em seu Dicionário Musical Brasileiro, publicado postumamente por Oneyda Alvarenga e Flávia Camargo Toni, ele dedica um verbete bastante longo à música de barbeiros. É curioso encontrar entre as fontes do dicionário as Memórias de Manuel Antônio, o que reforça a importância atribuída pelo musicólogo ao romance como fonte de pesquisa, fato amplamente destacado no prefácio à edição de 1941, já analisado acima.
}

Revista Lumen, v. 4, no 7, Jan./Jun. - 2019 - ISSN: 2447-8717 
religioso, como também uma manifestação da "cordialidade" brasileira, conforme conceituou Sérgio Buarque de Holanda em Raízes do Brasil. Em seu livro, o intelectual chamou a atenção para o fato de que Teresa de Lisieux fosse conhecida no Brasil como Santa Terezinha (HOLANDA, 1995). Esse tipo de aproximação parece estar presente também no texto do romance.

Outros trechos revelam aspectos mais gerais como, por exemplo, a rica paisagem sonora do Rio de Janeiro nos tempos do Rei. Como exemplo, recorda-se do capítulo com título D. Maria, ocasião em que o autor apresenta a personagem. Isso se dá no dia da Procissão dos Ourives. Logo no início do capítulo, o narrador informa que "[u]m dia de procissão foi sempre nesta cidade um dia de grande festa, [...] armavam-se coretos em quase todos os cantos" (ALMEIDA, 1995, p. 59-60). Logo adiante aparecem mais informações sobre a festividade, suas partes constituintes como o Rancho das Baianas e seus participantes, seus modos, costumes e vestimentas. Sem dúvida uma referência fundamental que permite se intuir sobre a ubiquidade da música pela cidade do Rio de Janeiro.

Pela riqueza de sua narrativa poderia ainda ser lembrado, nessa categoria, o capítulo XX, O fogo no Campo, em particular no momento em que avançava a festa e grande parte do local estava “já coberta daqueles ranchos sentados em esteiras, ceando, conversando, cantando modinhas ao som de guitarra e viola" (Id., Ibid., p. 70). Esse trecho em particular se destaca ainda por outra referência bastante rara no romance, porém muito cara aos artistas românticos: a "originalidade" brasileira. A passagem seguinte se encontra na sequência do trecho citado logo acima, Manuel Antônio de Almeida confessa que:

[f]azia gosto passar por entre eles, e ouvir aqui a anedota que contava um conviva de bom gosto, ali a modinha cantada naquele tom apaixonadamente poético que faz uma das nossas raras originalidades, apreciar aquele movimento e animação que geralmente reinavam. Era essa a parte (permitam-nos a expressão) verdadeiramente divertida do divertimento (Id., Ibid., p. 70). [Grifos nossos]

É interessante encontrar por aqui a expressão de um conceito bastante raro no romance, a originalidade de uma manifestação musical, e não qualquer uma, em geral, mas uma originalidade nossa, da nacionalidade brasileira. Esse dado reforça a presença de traços que, mesmo raros como dito anteriormente, aparentam as Memórias ao Romantismo, ainda que, de acordo com Antonio Candido, segundo um desenho mais complexo que aquele das classificações esquemáticas. Não é demais lembrar aqui um romance como $O$ Guarani de José de Alencar que - não obstante contabilizar entre sua publicação e sua sexta edição apenas 5.700 exemplares - tinha "intenções de produzir uma síntese do passado nacional” (GUIMARÃES, 2004, p. 99).

\section{FINALE: A MÚSICA SAI DE CENA}

Apesar da ubiquidade da música observada por todo o romance - presença marcante que a análise até aqui tentou enfatizar - a partir dos últimos capítulos, curiosamente, a sestrosa arte sai completamente 
de cena. O que poderia parecer enfraquecer a ideia da música funcionando como um vetor que conduziria os personagens da ordem para a desordem, na verdade, reforça essa tese. Isso porque, uma vez chegado ao capítulo XLIV, Leonardo se encontra na condição de oficial da guarda e sua incursão pelo universo da ordem é crescente e atinge o seu ápice justamente por ocasião de seu enlace com Luisinha. Isto é, até o final do livro no capítulo XLVIII, não haverá mais nenhuma escapada nem deslize, mesmo levando-se em conta os demais personagens, incluídos aí, aqueles de papel secundário. De certo modo, a música teria ficado sem função ou teria até mesmo se tornado inconveniente nessa altura do texto. Parece que, uma vez atingida a ordem, a única maneira de garantir a sua continuidade seria por meio do silêncio da arte dos sons. Aqui caberiam talvez duas observações para mostrar as contingências da ordem em uma sociedade como a brasileira e também os limites do casamento como instituição, pelo menos na visão do autor.

É visível por todo o romance certa equivalência entre ordem e desordem, aspecto que para Antonio Candido se efetiva em traço especial do livro, “em certa ausência de juízo moral e na aceitação risonha do 'homem como ele é', mistura de cinismo e bonomia” (CANDIDO, 1970, p. 79). Essa chave explica porque o próprio Manuel Antônio identificava no "compadresco", no tempo do Rei e dos leitores do texto, "uma mola real de todo o movimento social" (ALMEIDA, 1995, p. 142). Não obstante, o movimento de punição de Leonardo pela contribuição na fuga de Teotônio e o percurso em direção ao enlace final com Luisinha, tudo aparentemente dentro da ordem, os meios utilizados pelos personagens resvalam na lógica de uma sociedade de forte indistinção entre esses universos, como também alertou Antonio Candido. Exemplo contundente é que ambas, a Comadre e D. Maria, escolhem a Maria Regalada para interceder por Leonardo. Antigo caso amoroso do Vidigal, foi ela que, por meio da promessa de volta aos velhos tempos, salvou o personagem principal do livro. Lembremos que ao chegar na casa do Major, pego de surpresa pela visita - as três mulheres o encontraram de robe e tamancos - ele rapidamente completou o traje vestindo por cima parte de sua farda. Após sua rápida intervenção, o major se apresentou, do ponto de vista simbólico, como parte ordem e parte desordem. Sua figura incorporava ao mesmo tempo as duas esferas. Ainda em sua análise, Candido percebeu na sociedade daquele tempo (e por que não pensar no nosso também?) uma "[o]rdem dificilmente imposta e mantida, cercada de todos os lados por uma desordem vivaz" (CANDIDO, 1970, p. 82).

Ainda segundo Antonio Candido, apesar do romancista igualar esses momentos retirando qualquer escala necessária que tornam o leitor incapaz de fazer qualquer juízo de valor e mesmo que o narrador não atribuísse esse tipo de juízo aos relacionamentos de Leonardo com Luisinha e Vidinha, segundo Candido um par "admiravelmente simétrico", o crítico completa que "[c]omo Leonardo; o narrador parece aproximar-se do casamento com a devida circunspecção mas sem entusiamo". Mesmo assim, parece ter escapado a Antonio Candido uma passagem na parte final do livro em que é difícil não notar um juízo do narrador que revela, no mínimo, certo preconceito em relação às uniões fora da instituição do matrimônio.

Revista Lumen, v. 4, $\mathrm{n}^{\mathrm{o}}$ 7, Jan./Jun. - 2019 - ISSN: 2447-8717 
Antes de tudo, porém, os dois amavam-se sinceramente; e a ideia de uma união ilegítima lhes repugnava.

$\mathrm{O}$ amor os inspirava bem.

Esse meio de que falamos, essa caricatura da família, então muito em moda, é seguramente uma das causas que produziu o triste estado moral da nossa sociedade (ALMEIDA, 1995, p. 151).

Tendo presente esses limites, podemos concluir que talvez a pausa musical no final do livro se prenda mesmo a essa ausência de juízo, a esse olhar que tudo acolhe e que compreende a precariedade da ordem em uma sociedade como a brasileira. Essa ausência talvez revele também um pouco mais da visão de Manuel Antônio sobre a própria música. Não faria sentido a música ocupar papel de destaque como o ocupado em quase todo o livro em um momento em que a ordem se estabeleceu e foi coroada pelo casamento. O silêncio musical talvez se devesse à impossibilidade de uma arte tão sestrosa conduzir ou mesmo de manter os personagens dentro da ordem. Esse dado parece reforçar nossa tese. O ponto alto na "recuperação" de Leonardo, seu casamento com Luisinha, no contexto da obra, não teria como ocorrer com uma trilha sonora a provocar os personagens em novas transgressões.

Olhando um pouco mais de perto a possível relação de Manuel Antônio de Almeida com a música e tendo presente sua ausência de juízo moral em relação a ela, parece que ele antecipou uma percepção manifestada por Machado de Assis. Apesar da verdadeira ubiquidade da música por quase todo o livro, não existe no texto uma única referência a vida musical de concertos. Esse fato causa estranheza pois, com a insólita vinda da família real, a vida da corte foi transferida para o Brasil e sabe-se bem sobre o interesse e o apoio financeiro dos Bragança à prática da música, o que os levou a atuar como grandes patronos das artes. O mundo musical carioca nesses anos se transformou. Ambientado nesse período, as memórias não fazem qualquer referência a esse movimento de significativa efervescência musical. Outros autores, como José de Alencar, por exemplo, tiveram comportamento diferente em seus romances, dando especial atenção à ópera e à música de salão, como as valsas. Maneco parece ter pela música "séria" a mesma falta de entusiasmo citada em relação ao casamento, apesar de ter, conforme já citado, dirigido uma academia de ópera e até mesmo escrito um drama lírico nos moldes de Verdi. Por outro lado, o uso que ele fez de gêneros como a modinha e outros fados parece indicar certa simpatia e até mesmo preferência por essa modalidade de música. Essa é a trilha sonora do romance.

Retomando as aproximações com Machado de Assis, é oportuno relembrar que o autor das Memórias o conheceu em 1858. O jovem escritor trabalhava como aprendiz da Tipografia Nacional, no período em que Manuel Antônio era ali administrador. Para José Miguel Wisnik, "Machado de Assis foi quem primeiro percebeu - e muito precocemente, no apagar das luzes do Império - a dimensão abarcante que assumiria a música popular no Brasil, com instâncias a figurar e a exprimir, como nenhuma, a vida brasileira como um todo" (WISNIK, 2003, p. 60). O mesmo processo de mudança de percepção manifestado por Machado de Assis entre dois de seus contos - O Machete (1878) e Um homem célebre (1888) 
- se insinua na maneira como o diretor da Imperial Academia de Música e Ópera Nacional e libretista do drama lírico Dois Amores trata da música em suas Memórias. Na passagem de um conto para o outro, no período de mais ou menos dez anos, conforme explicou Wisnik, Machado abandonou a identificação com o mundo da cultura erudita ao perceber uma "fratura" no meio cultural brasileiro entre o repertório da música erudita, "que está longe de fazer parte de um sistema integrado de autores, obras, público e intérprete" e a música popular urbana. Machado de Assis acenou indiretamente, por intermédio do exemplo musical, para o abismo existente entre a cultura escrita e não escrita e, mais particularmente, à "posição da literatura e de seu reduzido público, no Brasil" (Id., Ibid., p. 20). É claro que acontecimentos fundamentais, como a publicação em 1872 do primeiro recenseamento realizado no país, devido a seus dados alarmantes sobre o analfabetismo, contribuíram decisivamente, entre outros fatores, para a criação dessa nova consciência social (GUIMARÃES, 2004, p. 85-104). Entretanto, não parece exagerado vislumbrar que, talvez por conta de sua forte intuição, o autor de melodramas e amigo do mulato compositor de modinhas Laurindo Rabelo, herdeiro talvez de alguma vocação musical modinheira do próprio, como aventado por Mário de Andrade, tivesse intuído, ainda durante o Segundo Império, a precariedade da cultura erudita no Brasil. De um modo muito especial, a maneira como Manuel Antônio de Almeida se reportou às práticas musicais de seu tempo e o modo simpático como envolveu seus personagens nessa rica trilha sonora, verdadeiro passaporte para a desordem, parece antecipar o olhar crítico, posteriormente concretizado nos textos de Machado de Assis.

\section{REFERÊNCIAS}

ALMEIDA, Manuel Antônio de. Memórias de um Sargento de Milícias. São Paulo: Ática, 1995.

ANDRADE, Mário de. Dicionário musical brasileiro. Belo Horizonte: Itatiaia, 1989.

ANDRADE, Mário de. Introdução. In: ALMEIDA, Manuel Antônio. Memórias de um Sargento de Milícias. São Paulo: Livraria Martins, 1941. p. 5-19 (Biblioteca de Literatura Brasileira, 1).

ANDRADE, Mário de. Memórias de um Sargento de Milícias. In: Aspectos da literatura brasileira. 6.ed. Belo Horizonte: Itatiaia, 2002.

BOSI, Alfredo. História Concisa da Literatura Brasileira. São Paulo: Cultrix, 1982.

BUDASZ, Rogério. Música ibérica e afro-brasileira na Babia nos séculos XVII e XVIII. Curitiba: DeArtes/UFPR, 2004.

BURKHOLDER, J. Peter et al. A History of Western Music. 8.ed. New York: Norton \& Company, 2010. CANDIDO, Antonio. Dialética da malandragem: caracterização das Memórias de um Sargento de Milícias. Revista do Instituto de Estudos Brasileiros, São Paulo: Universidade de São Paulo, n. 8, p. 67-89, jun. 1970.

DAMASCENO, Darcy. A atividade linguística nas Memórias de um Sargento de Milícias. Revista Brasileira de Filologia, São Paulo, v.2, tomo 2, p. 155-177, dez. 1956. 
GUIMARÃES, Hélio de Seixas. Os leitores de Machado de Assis: o romance machadiano e o público de literatura no século 19. São Paulo: Nankin Editorial; Edusp, 2004.

HOLANDA, Sérgio Buarque de. Raizes do Brasil. 26.ed. São Paulo: Companhia das Letras, 1995.

MEYER, Marlyse. Folhetim: uma história. São Paulo: Companhia das Letras, 1996.

MORAES, José Geraldo Vinci; SALIBA, Elias Thomé. O historiador, o luthier e a música. In: (orgs.). História e música no Brasil. São Paulo: Alameda, 2010. p. 9-32.

OTSUKA, Edu Teruki. Espírito rixoso: para uma reinterpretação das Memórias de um Sargento de Milícias. Revista do IEB, São Paulo, nº44, p.105-124, 2007.

ROSS, Alex. Escuta só: do clássico ao pop. São Paulo: Companhia das Letras, 2011.

SCHAFER, R. Murray. A afinação do mundo: uma exploração pioneira pela história passada e pelo atual estado do mais negligenciado aspecto do nosso ambiente: a paisagem sonora. Tradução: Marisa Trench Fonterrada. São Paulo: Editora da Unesp, 2001.

SCHWARZ, Roberto. Pressupostos, salvo engano, da "Dialética da Malandragem". In: Que horas são?: ensaios. São Paulo: Companhia das Letras, 1987.

TINHORÃO, José Ramos. A música popular no romance brasileiro (vol. I: séculos XVIII e XIX). 2.ed. São Paulo: Editora 34, 2000.

VERISSIMO, José. Um velho romance brasileiro. Estudos brasileiros (2 ${ }^{\mathrm{a}}$ série), Rio de Janeiro: Laemmert, p. 107-124, 1894.

WISNIK, José Miguel. Machado Maxixe: o caso Pestana. Teresa Revista de Literatura Brasileira, São Paulo: Editora 34, n. 4/5, p. 13-79, 2003. 